\title{
Apricot fruit chilling injuries during the cold storage affected by harvest maturity
}

\author{
Ezzat, A. \\ Department of Horticulture, Faculty of Agriculture, Kafelelsehikh University, Kafr El-Shaikh, Egypt \\ Author for correspondence: ahmed.kassem@agr.kfs.edu.eg
}

\begin{abstract}
Summary: The study aimed to find the effect of different maturity classes (up to the days after full blossom) on the post-harvest life of 3 different apricot varieties Gold Cot, Bergarouge and Flavor Cot in Hungary. The fruit harvested in a particular time 65, 75 and 85 days after full blossom and divided to three maturity classes (Class 1, 2 and 3, respectively). Fruit stored in cold storage for 7 days at temperature $1^{\circ} \mathrm{C}$. Fruits were investigated in regard to physical parameters (weight loss, fruit firmness and soluble solid content SSC) and chilling injuries. The results showed that the varieties followed different ways in regard to response to different maturity classes. The maturity class I for all the tested varieties recorded the lowest weight loss, while with the increasing maturity stage the weight loss percentage for all the varieties recoded high values. The firmness decreased with delayed harvesting for all the varieties. Data of the chilling injuries showed that all the fruits which harvested at maturity I, recorded the highest percentage of fruit with CI (chilling injuries) at 0 (48.5, 37.25 and 38.75\%) and CI class I (44.75, 35.75 and 39.75\%) for Bergarouge, Gold Cot, and Flavor Cot.
\end{abstract}

Ezzat, A. (2019): Apricot fruit chilling injuries during the cold storage affected by harvest maturity. International Journal of Horticultural Science 25(3-4): 28-31. https://doi.org/10.31421/IJHS/25/3-4/4712

Key words: apricot, maturity stage, chilling injuries, weight loss

\section{Introduction}

Apricot fruit is perishable fruit which characterized by high sensitivity to cold storage and long storage periods. Apricot fruit during storage develop many of physiological disorders like: gel breakdown or chilling, which characterized by an unhealth area then it develops to brown spots. The fruit which stored at $1{ }^{\circ} \mathrm{C}$ to $3{ }^{\circ} \mathrm{C}$ have short market life and lose flavor (Ezzat, 2018; Ezzat et al. 2017). Pit burn: which characterized by flesh tissue around the stone and get dark color when the fruit exposed to high temperature after cold storage.

There are many pre- and post-harvest factors which play roles to determine the chilling injuries in apricot fruit.

Most of Hungarian apricot production of apricot harvest occurs mainly in June and July, during that time, fruit is available in the market with large quantities. Within few days of keeping the fruit in room temperature after harvest Fruits get softening, and their quality and flavor reduce rapidly, resulting in extensive fruit damage and disrupt the market policy for the apricot industry and prices control (Cao et al., 2009). Therefore cold storage is a technique which can help to prolong the fruit storability and hence the fruit marketing but apricot fruit is coldsensitive and internal breakdown and fruit softening occur at low temperature (Ezzat, 2018; Ezzat et al. 2017; Jing et al., 2018).

The maturity stage at harvest showed high influence in postharvest fruit quality (Jing et al., 2018; Cao et al., 2009). Many scientific studies showed the effects of storage on chilling injury in apricots (Ezzat, 2018; Ezzat et al., 2017; Ezzat et al., 2012). They studied the effect of different chemical elicitors to increase the storability of apricot fruit under cold storage and shelf-life conditions. The objective of this study was to investigate the effects of harvest maturity stage on the incidence of chilling injury of apricots.

\section{Materials and methods}

\section{Fruit samples}

Cultivars Gold Cot, Bergarouge and Flavor Cot apricots fruits were harvested from private apricot orchard in Siófok (Somogy County, Hungary). The fruit were sorted to be homogenized in the size and maturation state. Fruits were precooled for 24 hours then the fruit were studied in the laboratory of the Institute of Horticulture, University of Debrecen. The full blossom dates for all tested varieties is shown in table 1 . The maturities classes were determined up to the days after full blooming as maturity class I (DAF $=65$ days), maturity II (DAF $=75$ days), and maturity class III (DAF $=85$ days) Fruit were stored at $1{ }^{\circ} \mathrm{C}$ and $90-95 \% \mathrm{RH}$ for 7 days then the fruit were examined for physical and chilling injuries. Each treatment was done in 3 times replications, using $3 \mathrm{~kg}$ of fruits for each maturity stage per replication.

\section{Physical fruit parameters}

Weight loss was measured as the percentage loss of the harvested weight. A digital balance (BL S3102 Precision Balance, Bel Engineering, Italy) was used. Fruit firmness was measured by a DUROFEL Agrosta firmness tester.

\section{Chilling injuries (CI)}

Apricot fruit CI symptoms were characterized by the presence of flesh browning which visually investigated and had given different scales as following: (0) no flesh browning; (1) 
browning covering $<25 \%$ of the surface area; (2) browning covering $\geq 25 \%$ but $<50 \%$ of surface area; (3) browning covering $\geq 50 \%$ but $<75 \%$ of surface area; (4) browning covering $\geq 75 \%$ of surface area according to (Ezzat et al. 2017; Wang et al. 2006). The chilling incidence were measured by using the following formula: (number of detected fruit/total investigated fruit number)x 100 .

The fruit was chilling scale 2 and above were considered defected fruit.

\section{Results and discussion}

\section{Physical parameters as affected by maturity classes}

Data in Figure 1 shows that the varieties had different behavior in regard to weight loss percentage upon the cold storage. The maturity class I for all the tested varieties recorded the lowest weight loss, while the with increasing maturity stage the weight loss percentage for all the varieties recoded high values. For Bergarouge fruit the maturity class II and III showed not high differences in regard to weight loss percentage. While this difference was obvious for the Gold Cot fruit. Weight loss in apricot was related for long storage period and over ripping of the fruit (Ezzat et al., 2012). Even most of post-harvest treatments aimed to reduce the water loss during storage by decreasing fruit respiration rate like using of MAP (Ezzat, 2018; Muftuoğlu et al., 2012).

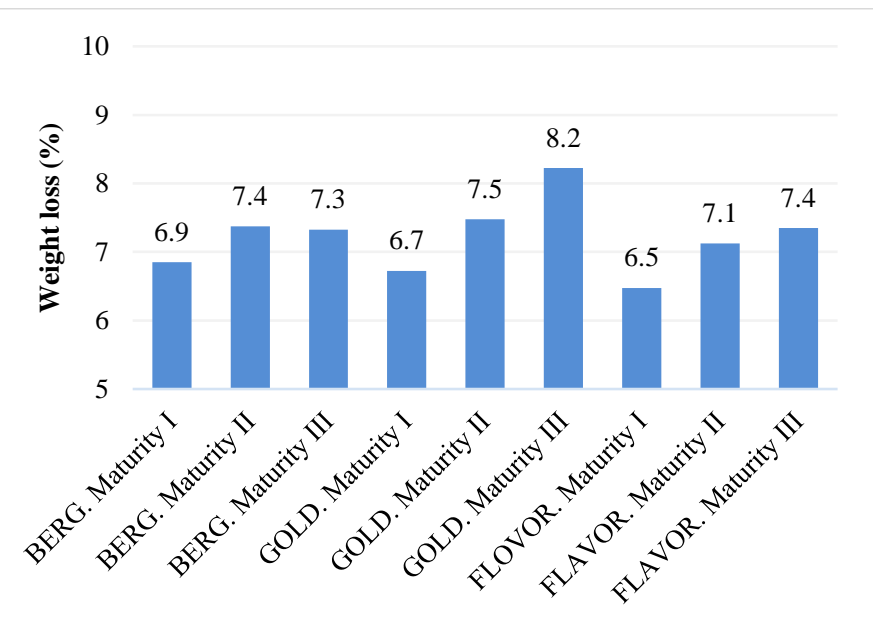

Figure 1. Effect of different harvest times (maturity classes) on the weight loss percentage of Bergarouge, Gold Cot and Flavor Cot apricot.

Fruit firmness data showed that the firmness decreased with delayed harvesting for all the varieties. Firmness showed sound reduction $3.45,3.3$ and $3.025 \mathrm{~N}$ for the harvested fruit at maturity class III for, Bergarouge, Gold Cot and Flavor Cot, respectively (Figure 2).

However, because the maturity for the 3rd class of fruit at harvest were quite mature, firmness decreased during storage (Jing et al. 2018) and the same also was noticed in Melon (Hatami et al. 2019). Even this finding was in the same way with most of the studies about apricot storability as the firmness decreases with increasing time of storage and fruit got more ripe (Ezzat, 2018; Ezzat et al. 2012; Ezzat et al., 2017). The varieties showed different behavior in regard to SSC and maturity classes (Figure 3). Bergarouge maturity class I SSC value was high (13.025) then decreased in maturity class II (12.647) then recorded highest value in maturity class III (13.715). Gold Cot fruit SSC value was recoded for maturity class I (14.48) then decreased for class II and III (13.96 and 13.225, respectively). While the opposite trend was noticed for Flavor Cot as the SSC value increased with the delaying of harvesting and the obvious highest value was for the maturity class III (14.53).

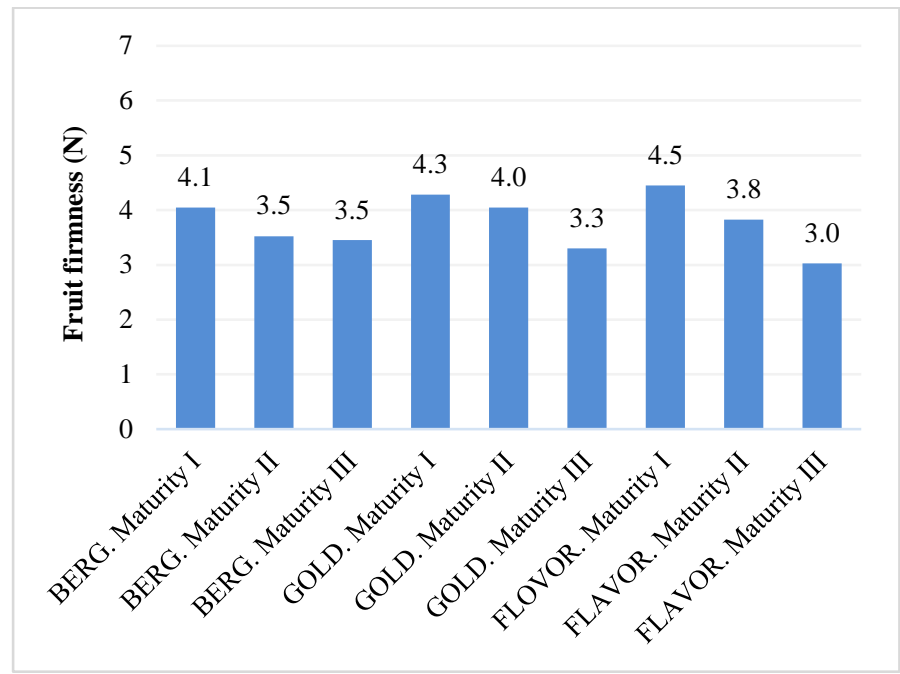

Figure 2. Effect of different harvest times (maturity classes) on the fruit firmness $(\mathrm{N})$ percentage of Bergarouge, Gold Cot and Flavor Cot apricot.

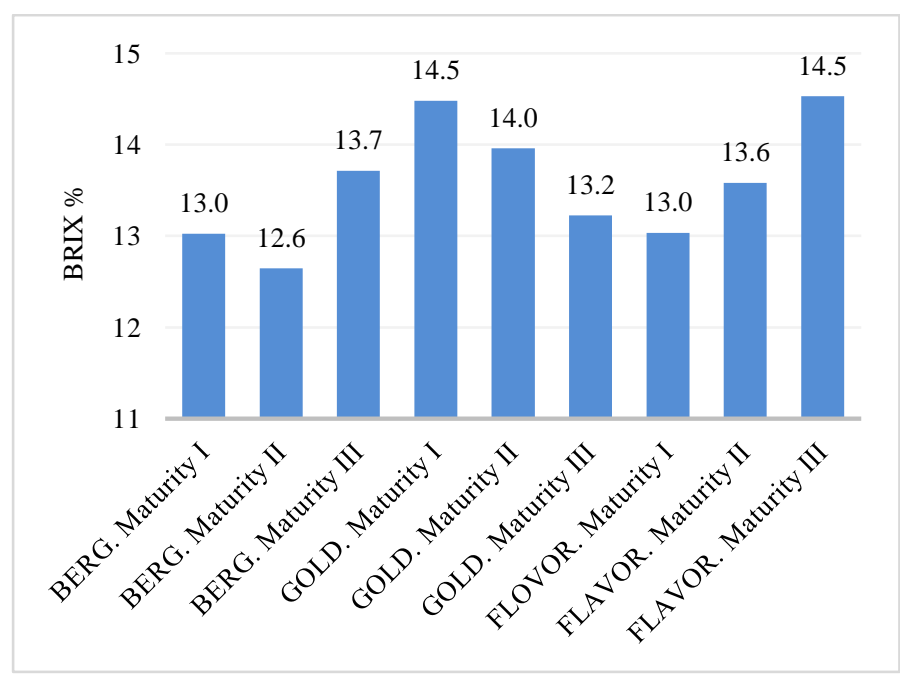

Figure 3. Effect of different harvest times (maturity classes) on the soluble solid content (Brix\%) of Bergarouge, Gold Cot and Flavor Cot apricot.

SSC decreased slightly in the first 7th day of storage but it did not change for the other storaged apricots (Muftuoğlu et al., 2012) while with over ripe fruit there was increase in SSC may because of water loss with the storage time (Ezzat et al., 2017). Pretel et al. (1999) also demonstrated that SSC and acidity did not change significantly under CA conditions during the storage period. Changes in most parameters showed that maturity increased in control fruit during storage at $4{ }^{\circ} \mathrm{C}$; while modified atmosphere packaging delayed this process.

\section{Chilling injuries and chilling incidence}

Data of the chilling injuries showed that all the fruit which harvested at maturity I, recorded the highest percentage of fruit with CI at $0(48.5,37.25$ and $38.75 \%)$ and CI class I (44.75, 35.75 and $39.75 \%$ ) for Bergarouge, Gold Cot and Flavor Cot. While if the fruit harvested at maturity III, data showed the trend of increasing the percentage of fruit with chilling injuries with 
classes 2, 3 and 4 (22.25, 24.75 and $9 \%$ for Bergarouge, 24.25, 27.5 and 14.5 for Gold Cot and 21.5, 25.75 and 13.5 for Flavor Cot) (Figure 4-6). This finding was supported by data presented in Figure 7 about fruit chilling incidence, with the delay of harvest the chilling injuries will be more occurred and recorded for the fruit from all the varieties.

Studies on peaches and loquats demonstrated that the higher fatty acid, the higher the stability of the cell membrane. These features increase the resistance of fruits to chilling (Musacchi \& Serra, 2018).

Ezzat et al. (2017) found that using of salicylic acid to prolong apricot storability and reducing the CI is maintained by decreasing membrane electrolyte leakage. The membrane electrolyte leakage increases with increasing the storage period or in over ripping fruit.

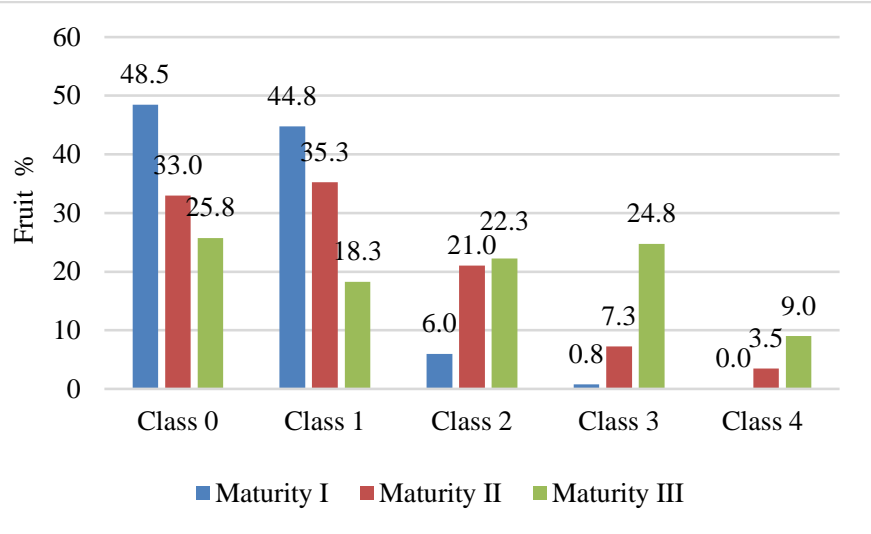

Figure 4. Effect of different harvest times (maturity classes) on chilling injuries percentage of Bergarouge apricot.

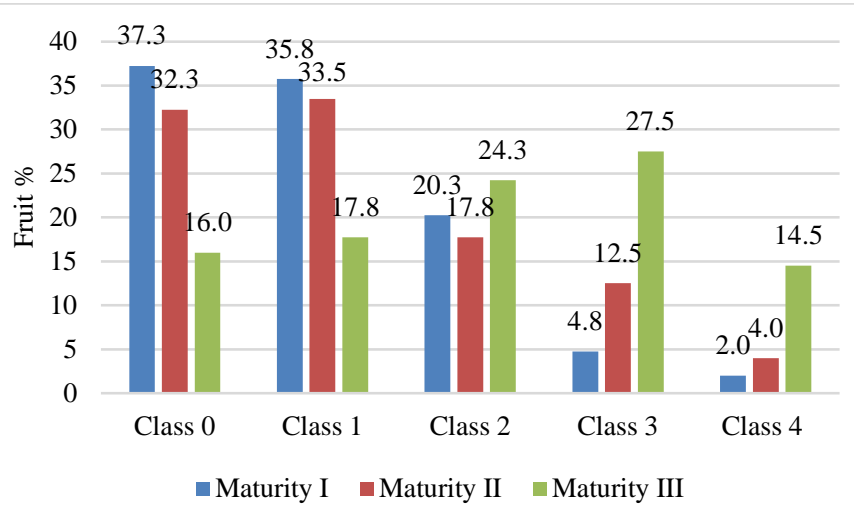

Figure 5. Effect of different harvest times (maturity classes) on chilling injuries percentage of Gold Cot apricot.

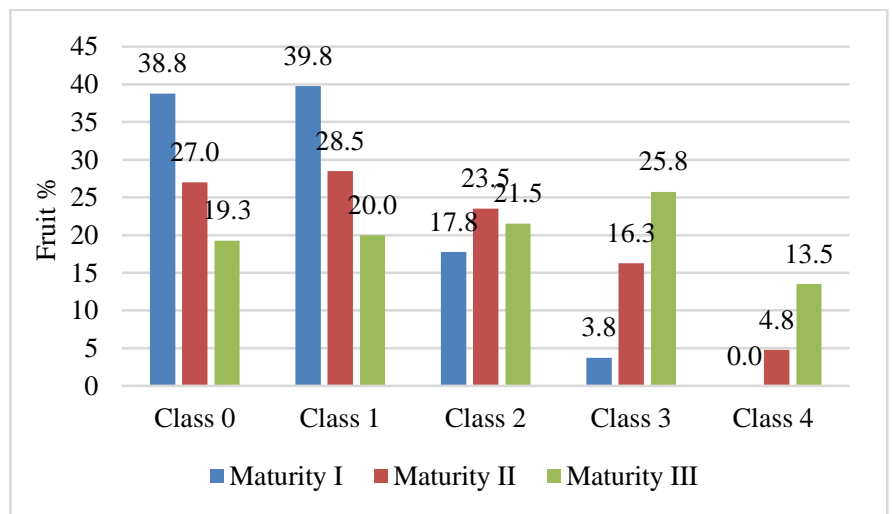

Figure 6. Effect of different harvest times (maturity classes) on Chilling

\footnotetext{
injuries percentage of Flavor Cot apricot.
}

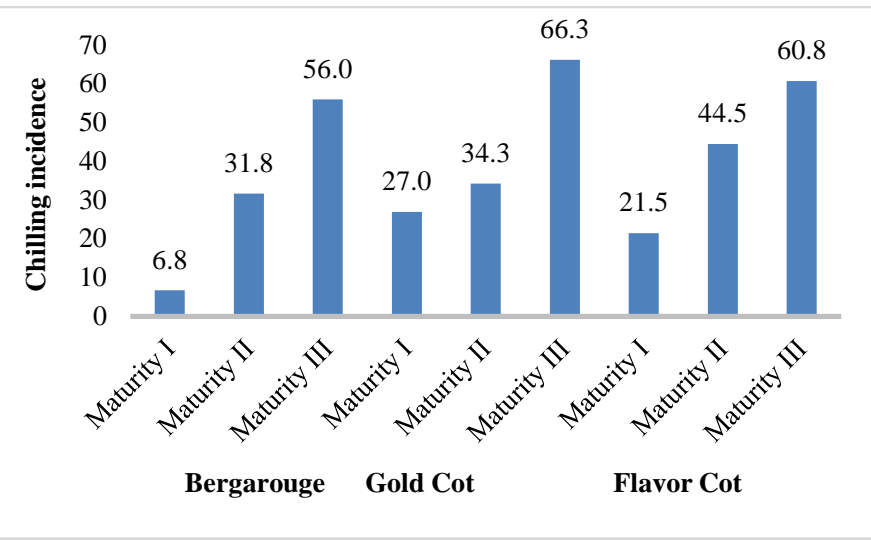

Figure 7. Effect of different harvest times (maturity classes) on chilling injuries percentage of Bergarouge, Gold Cot, and Flavor Cot apricot.

\section{Conclusions}

The maturity class of apricot which the fruit should be harvested is depending on many factors, like the variety and how far is the market. If the fruit harvest for domestic market and will not store for more than 5 days, then it can harvest in maturity class II or III, while the fruit which harvest for long distance market and will be shipped for more than 7 days, it should be harvested in maturity class I.

\section{References}

Cao, J. K., Zhao, Y. M., Wang, M., Lü, H. Y., Jiang, W. B. (2009): Effects of 1-Methylcyclopropene on Apricot Fruit Quality, Decay, and on Physiological and Biochemical Metabolism during Shelf-Life Following Long-Term Cold Storage. Journal of Horticultural Science and Biotechnology 84(6): 672-76. $\quad$ https://doi.org/10.1080/14620316.2009. 11512584

Ezzat, A. (2018): Effect of Modified Atmosphere Package on Apricot Fruit Storability. International Journal of Horticultural Science 24(3-4): 30-32. https://ojs.lib.unideb.hu/IJHS/ article/ view/2645.

Ezzat, A., Nyéki, J., Soltész, M., Amriskó, L., Balázs, G. I., Mikita, T., Szabó, Z. (2012): Storability of some apricot varieties as affected by storage period. International Journal of Horticultural Science. 18(1): 39-42. https://doi.org/10.31421/ IJHS/18/1/992

Ezzat, A., Ammar, A., Szabó, Z., Nyéki, J., Holb, I. (2017): Postharvest Treatments with Methyl Jasmonate and Salicylic Acid for Maintaining Physico-Chemical Characteristics and Sensory Quality Properties of Apricot Fruit during Cold Storage and Shelf-Life. Polish Journal of Food and Nutrition Sciences 67(2): 159-66. https://doi.org/10.1515/pjfns-2016-0013

Ezzat, A., Ammar, A., Szabó, Z., Holb, I. (2017): Salicylic Acid Treatment Saves Quality and Enhances Antioxidant Properties of Apricot Fruit. Horticultural Science 44(2): 73-81. https://doi.org/10.17221/177/2015-HORTSCI

Jing, Y., Ma, X., Jin, P., Zhu, X. (2018): Effects of Harvest Maturity on Chilling Injury and Storage Quality of Apricots. Journal of Food Quality. Special Issue 2018. https://doi.org/10.1155/2018/4954931 
Mohsen, H., Kalantari, S., Soltani, F., Beaulieu, J. C. (2019): Storability, Quality Changes, and General Postharvest Behavior of Dudaim Melon Harvested at Two Maturity Stages. HortTechnology 29(3): 241-50. https://doi.org/10.21273/ HORTTECH04057-18

Muftuoğlu, F., Ayhan, Z., Esturk O. (2012): Modified Atmosphere Packaging of Kabaaşi Apricot (Prunus Armeniaca L. 'Kabaaşi'): Effect of Atmosphere, Packaging Material Type and Coating on the Physicochemical Properties and Sensory Quality. Food and Bioprocess Technology 5(5): 1601-11. https://doi.org/10.1007/s11947-010-0482-6

Musacchi, S., Sara, S. (2018): Apple Fruit Quality: Overview on Pre-Harvest Factors. Scientia Horticulturae 234: 409-30. https://doi.org/10.1016/j.scienta.2017.12.057.
Pretel, M. T., Serrano, M., Amorós, A., Romojaro, F. (1999): Ripening and Ethylene Biosynthesis in Controlled Atmosphere Stored Apricots. European Food Research and Technology 209(2): 130-34. https://doi.org/10.1007/ s002170050471

Wang, L., Chena, S., Kong, W., Li, S. Archbold, D. D. (2006): Salicylic Acid Pretreatment Alleviates Chilling Injury and Affects the Antioxidant System and Heat Shock Proteins of Peaches during Cold Storage. Postharvest Biology and Technology 41(3): 244-51. https://doi.org/10.1016/j. postharvbio.2006.04.010 